\begin{tabular}{|c|c|c|}
\hline \multicolumn{3}{|c|}{ A N N A L E S } \\
\hline UN IV & MARIAE C & \\
\hline \multicolumn{3}{|c|}{ LUBLIN - POLONIA } \\
\hline VOL. XXIV, 1 & SECTIO K & 2017 \\
\hline
\end{tabular}

Faculty of International and Political Studies, Jagiellonian University

\title{
Prospects for United States of America-China Political and Economic Relations under Donald Trump's Presidency
}

\begin{abstract}
The purpose of this article was to introduce the possible future relations between China and the United States of America under Donald Trump's presidency. The paper is divided into five sections: economy, real challenges, trade policy and industry, diplomacy. Each of them is introducing key issues in terms of the main topic. The secondary point of this article was to show the gravity of change after the United States of America election results in December 2016 and the impact of this event on American policy toward China. The main conclusion which arose from the article is: during upcoming decade, USA-China relations are going to be extremely tense when compared with the previous years. Trade policy, Taiwan, strategic rapprochement of the United States of America with such countries as India and Russia, as well as innovation race across many industries, will remain a point of contention. The future of Sino-US relations will probably depend mostly on the emerging administration of the $45^{\text {th }}$ President of the United States of America.
\end{abstract}

Key words: China, United States of America, prospects, economic relations, political relations

\section{INTRODUCTION}

Zbigniew Brzeziński, a Polish-American political scientist and futurologist, predicted, in 1997, that the United States would be unmatched by any country in the world in terms of military, economic, technological and cultural strength. He put these assumptions in the epilogue of his book The Grand Chessboard. American Primacy and Its Geostrategic Imperatives [see: Brzeziński 1997]. Fourteen years later, developments made him revise his earlier hypotheses. In 2011, his next book was published under the title Strategic Vision: America and the Crisis of Global Power [see: Brzeziński 
2012], in which the title of the foreground actor threatening the economic hegemony of the United States was won by China. Relations between these countries in the $21^{\text {st }}$ century were changing at a very fast pace. The growing economic interdependence between them was affecting also the development and security on a global scale. The change at the highest level of government in the United States that occurred at the end of 2016, prompts a reflection on the future of the Washington-Beijing relations.

Despite numerous polls in favour of Hillary Clinton, an eccentric billionaire Donald Trump won, on November 9, 2016, the presidential election in the United States. During the entire electoral campaign, the leaders of the People's Republic of China observed with concern the course of political events. The potential victory of the Democratic Party candidate would mean confronting China with a policy which is often referred to as hostile towards the PRC. As early as 2010, Secretary of State Hillary Clinton caused widespread indignation in Beijing with her decision to recognize the South China Sea as the most important regional area in the context of US security. In addition, the well-known policy line promoting human rights protection, and the significant role Secretary Clinton played in the Asian pivot during the Barack Obama's presidency, was the reason why her candidature was not promoted in China [Tiezzi 2016]. Does this mean that her opponent, Donald Trump, has become a naturally better alternative to the future of Sino-US relations?

This paper is to show the possible future shape of relations between Washington and Beijing during the $45^{\text {th }}$ US Presidential term. It is to present opportunities, threats and real problems in the process of cooperation between the United States and China. It is especially important to look closely at top level relations because they affect the development of global policy.

\section{ECONOMY}

During the election campaign, Donald Trump presented a seven-step program aimed at restoring jobs in the United States. Among other things, he announced the pullout of the US from the Trans-Pacific Partnership. He called this agreement a disaster for the United States and announced negotiations on fair bilateral deals that would restore jobs in the country. Japan's Prime Minister Shinzō Abe pointed out that the Trans-Pacific Partnership would be meaningless without the United States. He also added that other member countries of this agreement were not prepared to support it if Trump's assurances are fulfilled. China refused to join the TPP, expecting that the agreement aimed to isolate them politically and economically. Trump's decision to withdraw from this economic agreement, that was negotiated for seven years, will also be detrimental to the PRC over the long term. Da Wei, expert in US affairs at the Chinese Institute for Contemporary International Relations, said that the United States' decision to withdraw from the TPP was a manifestation of the rejection of globalization by the United States. $\mathrm{He}$ also pointed out that China was the beneficiary of this process and any slowdown 
thereof is not welcome in the PRC. Da Wei stressed that Trump's trade policy could destroy relations between Washington and Beijing because it is associated with the promotion of "economic nationalism" [Woolf 2016].

Another point of Trump's seven-step plan was to ensure that China could expect from the United States severe fiscal restrictions as a penalty for manipulating the Chinese currency to the detriment of the United States. He mentioned that he would instruct the US Trade Representative to bring trade suits against both China and the World Trade Organization. In the last point, Donald Trump has announced that if China does not stop its "illegal activities" he will use all of the US President's legal prerogatives to remedy trade disputes between these countries in favour of the United States [Worstall 2016].

At the moment, the new administration in the United States is still developing, but in view of some assumptions made by the Republican candidate in the election campaign certain conclusions can be drawn. One of the most shocking public announcements about the economy was the decision to impose a $45 \%$ tax on goods imported from China. Opponents of this idea believe that such a move will not lead, as expected by the Trump administration, to restoring US jobs. This may, in turn, result in a decrease in GDP in China [Tan 2016].

In October 2016, the International Monetary Fund has published another World Economic Outlook to present the global economic development analysis by economists. In the fourth chapter, entitled Spillovers from China's Transition and from Migrations, the authors draw our attention to the global impact of changes occurring recently in the Peoples Republic of China. Fast, investment-based economic growth of China in the previous decade has stimulated the unprecedented world trade development and revived the commodity market. The impressive economic progress in China slowed down, but the country is still the world's second-largest economy and a key player in the world trade [Subdued Demand. Symptoms and Remedies 2016: 171-172].

The intelligence company Stratfor has prepared regularly, since 1996, forecasts for the forthcoming decades. The last one was published in 2015. According to the authors, China has now entered a new phase of the so-called normalization in economic development, preceded by a long-term high growth while keeping low wages. We can see now economic slowdown and the strengthening of dictatorship attitudes in China to resist various external influences that have arisen as a result of lower economic growth. China will remain one of the key economic powers but will fail to keep its former position as the driving force of the global economy. It is likely that the PRC will be replaced by a group of countries scattered across the world map, called the Post-China 16 (PC16) ${ }^{1}$. It will consist of selected countries in Asia, Africa and Latin America. The authors predict that some of these countries

1 The countries included in the PC16 group: Peru, the Philippines, Indonesia, the Dominican Republic, Nicaragua, Kenya, Mexico, Uganda, Vietnam, Cambodia, Laos, Sri Lanka, Tanzania, Bangladesh, Myanmar, Ethiopia. 
will take over the role the PRC played in the 1980s. This means that they will start an intense period of economic growth in the years to come. The authors assume that China will not achieve the status of an aggressive military power either. On the other hand, the United States will remain the main economic, political and military force in the world, but with less involvement than in the past. Due to the low export figures, increasing energy self-sufficiency and political experience of the past decade, the United States will increase the level of caution in terms of economic and military engagement in the world. In the forthcoming decade, one can expect a chaotic world with volatile power in many regions. According to the authors, the dominance of the United States will continue to be the only constant [Stratfor 2015].

\section{REAL CHALLENGES}

After the above-mentioned change in the field of economic development in China, the country will face new political and social challenges. The division between the coastal region - working closely with European and American consumers - and the interior which is not developing at the same dynamic pace, will be more vivid. In the coming decade the PRC will have to face these problems. Dictatorial tendencies are increasing in Beijing, and the anti-corruption campaign, which in fact serves the Chinese central government to continue the supremacy over the whole country, is still alive. The PRC follows a hybrid path to concentrate political and economic power, ensure Party's grip on the military, and consolidate the previously fragmented mining and steel industries. It is highly likely that the implementation of dictatorial elements in combination with an upgraded economic approach will produce the expected results. China is in the process of expanding its naval forces but at the same time has little experience in naval warfare, and there is a lack of experienced fleet commanders in that country, which is essential in confronting more experienced navies, especially US Navy [Stratfor 2015].

Donald Trump as President of the United States will have to make difficult decisions about which election promises, in the context of the policy towards China, to implement and which to reject. However, it is important to distinguish between the assertions of a Presidential Candidate on behalf of the Republican Party and their fulfilment by the already-sworn leader of the United States. Trump announced that as early as on the first day of his presidency he would officially stigmatize China for currency manipulation. However, it must be borne in mind that the fact of frauds in the PRC's monetary policy has been well known for about 40 years. Many other countries also employ such methods, but China is a rare case of overestimation of the currency value. Most countries are doing the opposite - they artificially lower their exchange rates to increase the competitiveness of exports. Of the six countries on the "watch list" created by the US Treasury Department, five cases deal with underestimating the currency levels [Babones 2016]. 


\section{TRADE POLICY AND INDUSTRY}

In October 2016, the US Treasury Department published the report on Foreign Exchange Policies of Major Trading Partners of the United States [2016]. It has disclosed the above-mentioned "watch list" of major trading partners. The purpose of the currency manipulation by the Chinese is to include the Yuan in the currency basket created by the International Monetary Fund. The only reasonable way for the US will be to continue watching China in terms of its currency policy. An important problem that could affect the future of the Sino-American relationship was Donald Trump's declarations of an alleged launch of a trade war with China in the future. According to Bloomberg News experts, China would be able to survive such a conflict with the United States. According to James Wang, professor at the City University of Hong Kong, the PRC government would be better prepared to organize government funding to mitigate the impact of the conflict on exporters. Kinger Lau Chief, a Chinese strategist working for Goldman Sachs, points out that the fiscal penalties announced by Trump for Chinese imports will lead to a decline in Chinese GDP and, as a result, will damage the global economy. Chinese exporters of "Walmart-type" goods, including clothing, furniture, footwear and textiles, will suffer significantly, while the effect of tax changes on telecommunications equipment will be less visible. In the United States, according to Wang, the war trade will undermine national consumption and will lead to inflation [Hu 2016].

China's aspirations to become a leader in semiconductor design and manufacture may be another bone of contention between Washington and Beijing. China plans to spend USD 150 billion on this goal within ten years. As a result, this is to provide the expected response to the continuing US competitiveness in this industry. The actions of the United States to maintain its leading position in this industry have been confirmed in a report published in January 2017 by the United States President's Council of Advisors on Science and Technology entitled Report to the President. Ensuring Long-Term U.S. Leadership in Semiconductors [2017]. In the document, the Council's Chair pointed out that the Chinese policy eliminated innovation from the market, thereby rendering the United States at risk. The fear of competition from the PRC can become a driving force for President Donald Trump in making strategic decisions about his biggest Asian partner. China, in turn, is prepared to possibly intensify inspections of US companies in the event Trump decides to penalize Chinese goods.

\section{GEOPOLITICS}

For decades, the question of Taiwan has been a point of contention in the USChina relations. The PRC considers this area its own territory and thus does not recognize the autonomy of the Government of the Republic of China in Taiwan. On the other hand, the United States has been supplying arms to Taiwan for many years, 
thus sustaining a years-long conflict on this matter with the PRC. On December 2, 2016, Donald Trump had a telephone conversation with the Taiwan government representative. It is worth noting that no US President has spoken with a Taiwan's leader since 1979, when the US officially broke diplomatic relations with Taipei recognizing the so-called "one China". In response, China's Foreign Minister Wang Yi said: "The 'one China' policy is the cornerstone of a healthy China-U.S. relationship. I hope this political foundation won't be disrupted or damaged" [Collinson 2016]. The next day after the leaders' conversation, the President-elect published information through Twitter that President Tsai Ing-wen made a congratulatory call. Nevertheless, the very fact of highlighting during the talks strong economic, political and security-oriented regional ties between the two countries has been a source of enormous controversy [Collinson 2016]. It is worth pointing out that the contact established between the leaders of the US and Taiwan coincided with a particularly hectic period in relations between Beijing and Taipei. Taiwan's leader Tsai Ing-wen, elected in 2016, did not support the earlier position that it is reasonable to recognize the one-China policy. Later on, in response to criticism of his conversation, Donald Trump posted the following on Twitter: "Interesting how the U.S. sells Taiwan billions of dollars of military equipment but I should not accept a congratulatory call" [Collinson 2016]. Pursuing the pro-Taiwan policy by the American leader will inevitably lead to political tensions between the United States and China in the future.

Another cause of concern for the People's Republic of China may be the growing activity of the President-elect in India. At this point, one should mention five real estate projects being implemented by the Trump Organization:

- Construction of a luxury 75-storey residential building “Trump Tower"containing 300 flats in cooperation with the Lodha Group in Mumbai;

- Construction of a 23-storey building in cooperation with Panchshil Realty in Pune;

- Giving the name "Trump" for a newly built office facility with the usable area of six hundred thousand square metres in Gurgaon;

- Tie-up between the Trump Organization and the high-end Indian developer $\mathrm{M} 3 \mathrm{M}$ for the construction of a residential building in Gurgaon;

- Tie-up between the Trump Organization and the Unimark Group regarding the construction of a 38-storey building with the usable area of four hundred thousand square metres in the area of Calcutta [Babar 2016].

Another issue which keeps Chinese diplomats awake is the announcement of political rapprochement between the United States and Russia. On Saturday, January 7, 2016, Donald Trump posted the following posts on Twitter: "Having a good relationship with Russia is a good thing, not a bad thing"; "Only fools would think that it is bad! We have enough problems in the world around us, we do not have to create a new one"; "During my presidency Russia will respect us much more than it did so far" [Syeed 2017]. Vladimir Putin sent to Donald Trump a greetings letter just before Christmas. The Russian President has expressed his hope that once 
the US leader is sworn in, relations between the United States and Russia would be transferred to a new, better level. Appropriate steps will be taken to restore the basis of bilateral cooperation between these countries. Even before the New Year, Vladimir Putin said in his speech that he intended to strengthen Russia's nuclear warfare capabilities. Trump responded to this via Twitter by posting: "The United States must greatly strengthen and expand its nuclear capability until such time as the world comes to its senses regarding nukes" [Graham 2016]. The current state between the two countries is described by the media as "frenemies". This term was created by combination of two English words: friend and enemy.

\section{DIPLOMACY}

At the beginning of December 2016, former US Secretary of State Henry Kissinger met with China's President Xi Jinping. The PRC's leader said that currently, after the results of the US election, both countries were in a crucial moment for their relationship. He stressed that China was closely watching the whole political situation. He further said that his country hoped for both development and stabilization in relations with the United States. The meeting of the politicians took place two weeks after Kissinger met the president-elect in New York. In an interview with CNN, Kissinger suggested that Trump should not be attached to all the promises made during the campaign. 93-year-old Kissinger described Trump as "the most unique" US future leader he had ever met in his career [Zhou 2016]. Bearing in mind that Henry Kissinger will now serve as a Trump's foreign policy advisor, it can be concluded that relations between the United States and Russia will improve. This can be demonstrated by the fact that in December 2016, Kissinger advised Trump to respect the fact that the Crimea is part of Russia [Buncombe 2016].

Zhang Zhizhou, professor at the School of International Relations and Diplomacy at the Beijing Foreign Studies University, pointed out that Chinese citizens were worried about the outcome of the election. The fact that the new US President has no experience in public service make them concerned, and they are afraid that he will not be able to maintain the Chinese-American relationship in good shape. Zhizhou underlined Kissinger's key role in shaping relations between these countries. Moreover, he drew attention to the fact that the former US Secretary of State agrees with the statement that the stable cooperation between the USA and China is a win-win relationship ${ }^{2}$. Kissinger is now seen in China as an intermediary in the exchange of views between Beijing and Washington. Professor Chu Shulong, Director of the Institute for International Strategic Studies and Development at Tsinghua University in Beijing, hopes that the interest of Kissinger will also include informing the US administration about concerns that have grown on the Chinese side since November 2016 [Zhou 2016].

\footnotetext{
2 Win-win relationship: for the benefit of both parties.
} 


\section{CONCLUSIONS}

To sum up the above considerations, it is worth noting that Donald Trump's victory in the presidential election opened a new chapter in US relations with China. Everything will now depend on which of the election promises made by the candidate of the Republican Party will be implemented. Nevertheless, a realistic look at the facts makes us to reflect that the forthcoming decade will be full of tensions between these countries. Trade policy, Taiwan, strategic rapprochement of the United States with such countries as India and Russia, as well as innovation race across many industries, will remain a point of contention. The most beneficial solution for global policy, however, would be to maintain a stable and peaceful relationship between Washington and Beijing. It should be hoped that the emerging administration of the $45^{\text {th }}$ President of the United States will mostly bear in mind the sustainable, global economic development that is nowadays heavily dependent on fruitful cooperation between the People's Republic of China and the United States.

\section{BIBLIOGRAPHY}

Babar, K. 2016. Trump eyes super luxury realty projects in India, "The Economic Times", 21 March, http:// economictimes.indiatimes.com/wealth/real-estate/trump-eyes-super-luxury-realty-projects-in-india/ articleshow/51487470.cms (access: 08.01.2017).

Babones, S. 2016. Trump's Gift to China. What Beijing Stands to Gain From His Policies "Foreign Affairs", 16 November, https://www.foreignaffairs.com/articles/china/2016-11-16/trumps-gift-china (access: 07.01.2017).

Brzeziński, Z. 2012. Strategic Vision: America and the Crisis of Global Power, Basic Books, New York.

Brzeziński, Z. 1997. The Grand Chessboard: American Primacy and Its Geostrategic Imperatives, Basic Books, New York.

Buncombe, A. 2016. Henry Kissinger has 'advised Donald Trump to accept' Crimea as part of Russia, "Independent", 27 December, http://www.independent.co.uk/news/people/henry-kissinger-russiatrump-crimea-advises-latest-ukraine-a7497646.html?amp (access: 08.01.2017).

Collinson, S. 2016. China lodges complaint over Trump-Taiwan call, "CNN Politics", 4 December (access 06.01.2017).

Decade Forecast: 2015-2025, 2015. Stratfor, "Worldview”, February.

Graham, D. 2016. Donald Trump's Hot-and-Cold Bromance with Vladimir Putin, "The Atlantic", 24 December, https://www.theatlantic.com/politics/archive/2016/12/trump-putin-so-true/511679/ (access: 08.01.2017).

Hu, B. 2016. China Would Outlast U.S. in Trade War, Billion-Dollar Fund Says, "Bloomberg", 29 December, https:/www.bloomberg.com/news/articles/2016-12-29/china-would-outlast-u-s-in-trade-war-pineriver-letter-says (access: 08.01.2017).

Report to Congress. Foreign Exchange Policies of Major Trading Partners of the United States, 2016. U.S. Department of the Treasury, April.

Report to the President. Ensuring Long-Term U.S. Leadership in Semiconductors, 2017. Executive Office of the President President's Council of Advisors on Science and Technology, January.

Subdued Demand. Symptoms and Remedies, 2016. International Monetary Fund, "World Economic Outlook", October. 
Syeed, N. 2017. Trump Says Only 'Fools' See Good Ties With Russia as Bad, "Bloomberg Politics", 6 January, https://www.bloomberg.com/politics/articles/2017-01-06/u-s-says-putin-ordered-russianhacking-during-the-2016-election (access: 08.01.2017).

Tan, H. 2016. A 45\% tariff on China will hurt US consumers, Capital Economics says, "CNBC", 29 September, http://www.cnbc.com/2016/09/29/us-presidential-election-news-trumps-tariff-plan-forchinese-goods-will-hurt-us-consumers.html (access: 07.01.2017).

Tiezzi, S. 2016. Why China Dreads a Hillary Clinton Presidency, "The Diplomat", 10 February, http:// thediplomat.com/2016/02/why-china-dreads-a-hillary-clinton-presidency/ (access: 06.01.2017).

Woolf, N. 2016.Trump to withdraw from Trans-Pacific Partnership on first day in office, "The Guardian", 22 November, https://www.theguardian.com/us-news/2016/nov/21/donald-trump-100-days-plansvideo-trans-pacific-partnership-withdraw (access: 06.01.2017).

Worstall, T. 2016. Donald Trump Campaigns By Threatening China Trade War - Possibly Not a Good Idea, "Forbes", 29 June, https://www.forbes.com/sites/timworstall/2016/06/29/donald-trump-campaigns-by-threatening-china-trade-war-possibly-not-a-good-idea/\#15fac9ca5c14 (access: 06.01.2017).

Zhou, L. 2016. Here's what China's Xi Jinping told Henry Kissinger about the Trump transition, "Business Insider", 2 December, http://www.businessinsider.com/china-xi-jinping-henry-kissinger-trump-transition-2016-12?IR=T (access: 08.01.2017).

\section{BIOGRAPHY}

Agnieszka Mazur, $\mathrm{PhD}$ student at the Faculty of International and Political Studies of the Jagiellonian University. Scientific interests: public choice theory, United States of America-China relations, international relations in the Asia-Pacific Region. E-mail: agnieszkaa.mazur@interia.pl 